Gelanggang Olahraga: Jurnal Pendidikan Jasmani dan Olahraga

Volume 2, Nomor 1, Juli-Desember 2018

e-ISSN : 2597-6567

p-ISSN : 2614-607X

DOI : https://doi.org/10.31539/jpjo.v2i1.325

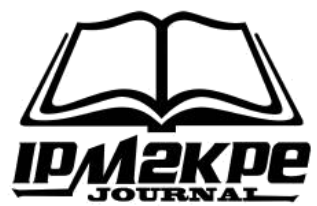

\title{
PENGARUH LATIHAN SIDE-TO-SIDE SHUFFLE JUMP TERHADAP PENINGKATAN DAYA LEDAK OTOT TUNGKAI
}

\author{
Arfon Meirony ${ }^{1}$, Lucy Oktavani ${ }^{2}$ \\ Pendidikan Jasmani Kesehatan dan Rekreasi, Universitas Bung Hatta ${ }^{1,2}$ \\ arfonmeirony@bunghatta.ac.id ${ }^{1}$
}

\begin{abstract}
ABSTRAK
Tujuan penelitian ini untuk mengetahui pengaruh latihan side-to-side jump terhadap peningkatan daya ledak otot tungkai. Penelitian ini mneggunakan metode eksperimen, teknik menentukan sampel purposive sampling. dengan 17 Sampel diberi tes awal vertical jump (modified sargent jump) dan dilanjutkan dengan perlakuan 14 kali pertemuan, lanjut tes akhir untuk melihat pengaruh latihan. Uji yang digunakan adalah t-test, melihat pengaruh rerata hitung signifikan $\alpha 0,05$. Hasil rerata post test (mean) 98,26, rerata pree test (mean) 100,45. Hasil pengujian $t_{\text {hitung }}(6,22)>t_{\text {tabel }}(2,11)$, dengan demikian hipotesis penelitian diterima. Simpulan, latihan Side-to-Side Shuffle Jump berpengaruh terhadap peningkatan daya ledak otot tungkai mahasiswa Pendidikan Jasmani, Kesehatan dan Rekreasi Universitas Bung Hatta
\end{abstract}

Kata Kunci: Side-to-Side Shuffle Jump, Daya Ledak Otot Tungkai.

\begin{abstract}
The purpose of this study was to determine the effect of side-to-side jump training on increasing leg muscle explosive power. This research was an experimental research. The sampling technique used in the research was purposive sampling with 17 samples that were given an early test of vertical jump (modified sargent jump) and followed by the treatment of 14 sessions. The latest test was the post test to see the effect of the exercise. T-test was used to see the effect of the significant mean $\alpha 0,05$. The results of the posttest mean was 98.26 and preetest mean was100.45. The hypothesis research was accepted because the result of ttest (6.22)>ttable (2.11). Conclusion, Side-to-Side Shuffle Jump exercises affect the increase of explosive limb muscle strength of Bung Hatta University Physical, Health and Recreation Education
\end{abstract}

Keywords: Side-to-Side Shuffle Jump, Leg Muscles Explosive Power 


\section{PENDAHULUAN}

Seiring dengan perkembangan zaman, maka pengetahuan dan pemahaman masyarakat Indonesia akan pentingnya olahraga mulai meningkat. Perkembangan olahraga tidak hanya untuk olahraga kebugaran, tetapi turut berkembang olahraga prestasi serta olahraga rekreasi. Hal ini dibuktikan dengan semakin banyaknya bermunculan pusat-pusat kebugaran dan perkumpulan-perkumpulan olahraga di Indonesia dan khususnya di daerah-daerah. Selain itu dengan telah banyaknya bermunculan pusat-pusat kebugaran dan perkumpulan-perkumpulan olahraga maka dituntut juga orang-orang yang paham akan bagaimana meningkatkan kemampuan olahraga tersebut yaitu seorang pelatih. Pelatih merupakan orang yang dapat merancang dan membimbing rangkaian latihan dengan tujuan meningkatkan kemampuan orang yang dilatih, seorang pelatih merancang dan mengembangkan potensi seseorang olahragawan atau atlet mampu tampil dengan performa yang maksimal dan menikmati aktifitas olahraga dengan baik serta sepenuh hati oleh karena itu pelatih perlu menyiapkan sebuah latihan terencana dengan baik.

Secara garis besar latihan merupakan suatu proses latihan yang tersusun secara sistematis serta terencana dengan tujuan untuk meningkatkan kemampuan fisik seorang Atlet atau orang berlatih (olahragawan) untuk mencapai sebuah tujuan yang diinginkan, sehingga terciptalah sebuah kemampuan yang dapat memenuhi keinginan dari pelatih dan olahragawan tersebut. Selain itu latihan tidak hanya untuk meningkatkan kemampuan fisik saja, tetapi dapat juga digunakan untuk meningkatkan kemampuan teknik dan psikologi.

Bentuk dari program latihan bermacam-macam sesuai dengan tujuan dan kebutuhan apa yang diinginkan oleh seorang pelatih dan olahragawan secara garis besar bentuk program latihan ditentukan oleh 5 unsur kondisi fisik yaitu: 1) kekuatan, 2). kecepatan, 3). daya tahan, 4) kecepatan dan 5) koordinasi. Dari kelima unsur tersebut pelatih dan olahragawan menganalisa bentuk olahraga yang akan dilatihnya serta baru ditentukan bentuk latihan apa yang akan diberikan kepada objek (olahragawan). Dengan telah berkembangnya keilmuan dalam kepelatihan olahraga semua unsur tersebut juga dapat dilaksanakan dalam satu satuan latihan (satu program latihan jangka panjang) dengan mempertimbangkan asupan gizi dari objek itu sendiri.

Dari sekian banyak fokus latihan yang mempengaruhi kondisi fisik, daya ledak (exsplosive power) menjadi fokus dalam penelitian ini, daya ledak hampir digunakan dibanyak cabang olahraga dan umum dilakukan oleh manusia dalam kehidupan sehari-hari. Menurut Bompa dalam Syafruddin (2013) "mendefinisikan daya ledak sebagai produk dari dua kemampuan yaitu kekuatan (strength) dan kecepatan (speed) untuk melakukan force maksimum dalam waktu yang sangat cepat". Jadi daya ledak (exsplosive power) kemampuan seorang manusia dapat bergerak dengan cepat bersamaan dengan kekuatan yang besar, selain itu daya ledak dapat difokuskan kepada salah satu dari anggota gerak tubuh seperti tungkai, tungkai atau bagian pinggang kebawah (dari pinggul sampai telapak kaki) banyak dimanfaatkan dalam kehidupan sehari-hari seperti berjalan, berlari, menganyuh sepeda dan lain sebagainya.

Melihat pentingnya daya ledak otot tungkai baik itu saat berolahraga maupun untuk kehidupan sehari-hari peneliti tertarik untuk membuktikan peningkatan daya ledak otot tungkai dengan mengunakan latihan Side-to-Side 
Shuffle Jump, Side-to-Side Shuffle Jump merupakan sebuah gerakan sederhana yang dapat dilakukan oleh siapa saja dan tidak harus dilakukan di tempat-tempat kebugaran dan latihan. Latihan ini hanya memerlukan tempat yang datar dan memiliki sirkulasi udara yang baik, membutuh dua (2) buah penanda yang jarak antar kedua tanda sekitar satu setengah $(1,5)$ meter, seperti program latihan yang dipublikasikan pada sebuah website luar negeri. Dalam web tersebut hanya memberikan bentuk gerakan tampa memberikan sebuah program latihan yang dapat dimanfaatkan oleh masyarakat umum, dan terbatas oleh seorang olahragawan yang paham tentang program latihan. https://www.msn.com/id$\mathrm{id} /$ kesehatan/latihan/kekuatan/side-to-side-shuffle-jump/.

\section{KAJIAN TEORI}

Program adalah rancangan mengenai asas-asas (dasar cita-cita) serta usaha-usaha, seterusnya latihan suatu kegiatan yang dilakukan secara bertahap, dalam jangka waktu yang relatif lama, dilakukan oleh perorangan yang tujuannya untuk meningkatkan kinerja secara fisiologis dan psikis untuk memenuhi tugas (prestasi yang harus dicapai) (Zulvikar, 2016), dan lebih lanjut lagi latihan olahraga merupakan suatu proses yang sistematis dari berlatih yang dilakukan secara berulang-ulang dengan menggunakan prinsip penambahan beban (Herre, 1982; Bompa, 1990 dalam bafirman, 2013) serta lebih spesifik Program latihan adalah seperangkat kegiatan dalam berlatih yang diatur sedemikian rupa sehingga dapat dilaksanakan oleh siswa pelajar atau atlet, baik mengenai jumlah beban latihan maupun intensitas latihannya. (J Tangkudung, dalam Candra, 2013).

Menurut ahli "daya ledak merupakan perpaduan atau kombnasi antara kekuatan dan kecepatan" (Syafruddin, 2013) selanjutnya, "daya ledak berada antara kekuatan maksimal dan kecepatan gerakan yang cenderung bergerak lebih kearah kecepatan gerakan atau kearah kekuatan maksimal menurut besarnya beban/hambatan" (Letzelter dalam Syafruddin, 2013) jadi daya ledak lebih cenderung membutuhkan kekuatan otot yang cepat sehingga dapat menghasilkan kemampuan gerak yang diiginkan.

Otot adalah sebuah jaringan konektif yang tugas utamanya adalah berkontraksi yang berfungsi untuk menggerakkan bagian-bagian tubuh baik yang di sadari maupun yang tidak di sadari. Menurut letaknya otot tungkai dibagi menjadi tiga bagian, yaitu otot-otot tungkai bagian atas, otot-otot tungkai bagian bawah dan otot-otot kaki. Faktor-faktor yang mempengaruhi daya ledak otot adalah: 1) banyak sedikitnya macam fibril otot putih, 2) kekuatan dan kecepatan otot, 3) koordinasi gerak yang harmonis, 4) tergantung banyak sedikitnya zat kimia dalam otot, dan 5) pelaksanaan teknik yang betul. Dua unsur penting dalam daya ledak yaitu: (a) kekuatan otot dan (b) kecepatan, dalam mengerahkan tenaga maksimal untuk mengatasi tahanan (Andryani, Pt Devi. et.al (2014)).

Latihan ini merupakan latihan kekuatan otot tungkai. Latihan Side-to-Side Shuffle Jump merupakan bentuk latihan sederhana yang dapat dilakukan dimana saja dan tanpa alat. Pelaksanaan latihan hanya perlu tempat yang datar dan memiliki sirkulasi udara yang baik, membutuh dua (2) buah penanda yang jarak antar kedua tanda sekitar satu setengah $(1,5)$ meter. Lingkup yang dilatih dalam latihan tersebut adalah otot tungkai, sehingga dengan latihan tersebut diharapkan akan memberikan perbedaan pada peningkatan daya ledak otot tungkai, 


\section{METODE PENELITIAN}

\section{Tes awal (pree test)}

Tes awal yaitu tes yang dilakukan sebelum diberikan perlakuan, mengunakan tes vertical jump (modified sargent jump), dimana setiap sampel melakukan tes tiga (3) kali pengulangan dan diambil hasil yang terbaik.

\section{Perlakuan (treatment)}

Setelah dilakukan tes awal, berikutnya dilaksanakan latihan side-to-sideshuffle-jump selama 8 minggu dengan intesitas $2 \mathrm{x}$ (dua kali) pertemuan dalam 1 minggu dengan jumlah total pertemuan sebanyak $14 \mathrm{x}$ (empat belas kali), sehingga lamanya perlakuan kurang-lebih selama 2 (dua) bulan,

\section{Tes akhir}

Pada petemuan ke 15 (lima belas), dilakukan pengukuran kembali tes vertical jump (modified sargent jump) untuk melihat besaran peningkatan program latihan selama 2 (dua) bulan tersebut.

Peubah yang akan diamati adalah melihat kemampuan daya ledak (exsplosive power) otot tungkai yang diukur mengunakan vertical jump (modified sargent jump), fungsinya untuk melihat selisih dari jangkauan dengan raihan (Widiastuti, 2015). Selanjutnya Untuk menghitung daya ledak otot tungkai menggunakan rumus Monogram Lewis.

\section{$\mathrm{P}=\sqrt{4,9} \mathrm{x}($ Weight $) \sqrt{\mathrm{L}}$}

Keterangan :

$\mathrm{D}=$ Hasil dari $(\mathrm{X}-\mathrm{Y})$ di ubah satuannya menjadi meter.

Weight $=$ Berat badan

$\mathrm{P} \quad=$ Hasil daya ledak otot tungkai

Metode yang digunakan dalam penelitian ini adalah penelitian eksperimen. "memungkinkan peneliti sedini mungkin untuk mengontrol variabel bebas dan variabel yang lain sehingga tingkat kepastian jawaban penelitian jauh lebih terkontrol dibandingkan dari jenis penelitian ex post facto" (Yusuf, 2003). Oleh karena itu peneliti mempunyai keuntungan untuk meramalkan kemampuan daya ledak otot tungkai dengan memberikan program latihan Side-to-Side Shuffle Jump

Teknik menentukan sampel menggunakan metode purposive sampling dimana "dilandasi tujuan atau pertimbangan-pertimbangan tertentu telebih dahulu" (Yusuf, 2003). Hal yang menjadi pertimbangan dalam penelitian ini, yakni (1) masih berstatus mahasiswa aktif, (2) berjenis kelamin pria, (3) berbadan sehat, (4) bersedia meluangkan waktu untuk dijadikan sampel penelitian

Pendeskripsian data dan pengujian hipotesis dalam penelitian ini diolah dengan memakai statistik deskriptif dan inferensial dengan rumus uji t sampel terikat. Sebelum dilakukan analisis uji t, terlebih dahulu dilakukan uji persyaratan analisis. 


\section{HASIL PENELITIAN}

Pada bagian ini akan dipaparkan hasil temuan dalam penelitian, diluar dari kendala-kendala yang dialami selama melakukan proses penelitian. Sebelum masuk pada bagian pembahasan perlu dilaksanakan persyaratan analisis terlebih dahulu.

\section{Uji Normalitas}

Uji normalitas mengunakan uji liliefors dengan $\mathrm{L}_{\text {tabel }}$. 0,2149 yang didasarkan pada jumlah sampel $(\mathrm{N}=17)$ pada tabel uji liliefors dengan taraf signifika $\alpha 0,05$, menunjukan data berdistribusi normal, hasil uji liliefors dapat dilihat pada tabel berikut:

Tabel 1.

Uji Normalitas Data Penelitian

\begin{tabular}{ccccc}
\hline Sumber Data & $\mathbf{N}$ & $\mathbf{L}_{\mathbf{0}}$ & $\mathbf{L}_{\text {tab }}$ & Kesimpulan \\
\hline Post Test & \multirow{2}{*}{17} & 0,1698 & \multirow{2}{*}{0,2149} & Normal \\
Pree Test & & 0,1253 & & Normal \\
\hline
\end{tabular}

\section{Uji Homogenitas}

Uji homogenitas mengunakan uji homogenitas variansi dilakukan untuk mengetahui apakah data dalam variabel $\mathrm{X}_{1}$ dan $\mathrm{X}_{2}$ bersifat homogen atau tidak. dengan $\mathrm{F}_{\text {tabel(17-1)(2-1) }}$. 4,49 yang didasarkan pada jumlah sampel $(\mathrm{Ft}=17)$ dengan taraf signifika $\alpha 0,05$, menunjukan data berdistribusi homogen dapat dilihat pada tabel berikut:

Tabel 2.

Uji Homogenitas Data Penelitian

\begin{tabular}{cccccc}
\hline $\mathbf{U j i}$ & $\boldsymbol{\alpha}$ & $\mathbf{n}$ & $\mathbf{F h}$ & $\mathbf{F t}_{(\mathbf{1 7 - 1 ) ( 2 - 1 )}}$ & Ket \\
\hline $\mathrm{X} 1 \mathrm{X} 2$ & 0,5 & 17 & 1,071 & 4,49 & Homogen \\
\hline
\end{tabular}

\section{Post Test}

Dari hasil pelaksanaan tes awal (Post Test) dimana sampel melaksanakan tes vertical jump (modified sargent jump), dimana setiap sampel dapat melakukan tiga (3) kali pengulangan tes dan diambil hasil yang terbaik dan dilanjutkan dengan menggunakan rumus Nomogram Lewis. Didapat nilai tes awal (Post Test) tertinggi 160,28 dan terendah 67,54, dengan rata-rata 98,26. Untuk lebih jelasnya dilihat dalam kelas interval tes awal sebagai berikut: 
Tabel 3.

Sebaran Data Kelas Interval Post Test

\begin{tabular}{ccc}
\hline Kelas Interval & $\begin{array}{c}\text { Frekwensi } \\
\text { Absolute (FA) }\end{array}$ & $\begin{array}{c}\text { Frekwensi } \\
\text { Relative (FR) }\end{array}$ \\
\hline $67,54-86,14$ & 7 & 41,18 \\
$86,15-104,75$ & 3 & 17,65 \\
$104,76-123,36$ & 5 & 29,41 \\
$123,37-141,97$ & 1 & 5,88 \\
$141,98-160,58$ & 1 & 5,88 \\
& 17 & 100 \\
\hline
\end{tabular}

Untuk lebih jelasnya dapat dilihat pada histogram berikut:

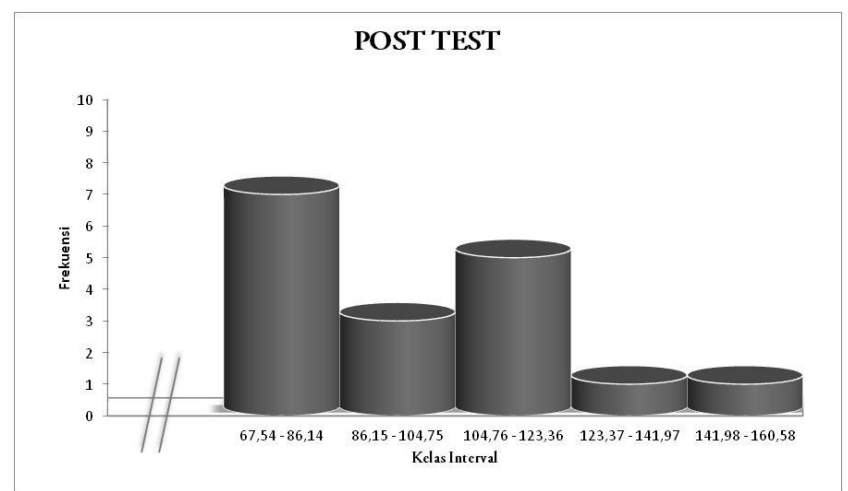

Gambar 1. Histogram Kelas Interval Post Test

\section{Pree Test}

Dari hasil pelaksanaan tes akhir (Pree Test) dimana sampel kembali diberikan tes vertical jump (modified sargent jump), dimana setiap sampel dapat melakukan tiga (3) kali pengulangan tes dan diambil hasil yang terbaik. Didapat nilai tes akhir (Pree Test) tertinggi 153,99 dan terendah 71,57, dengan rata-rata 100,45 . Untuk lebih jelasnya dilihat dalam kelas interval tes awal sebagai berikut:

Tabel 4.

Sebaran Data Kelas Interval Pree Test

\begin{tabular}{ccc}
\hline Kelas Interval & $\begin{array}{c}\text { Frekwensi } \\
\text { Absolute (FA) }\end{array}$ & $\begin{array}{c}\text { Frekwensi } \\
\text { Relative (FR) }\end{array}$ \\
\hline $71,57-88,05$ & 7 & 41,18 \\
$88,06-104,53$ & 3 & 17,65 \\
$104,54-121,02$ & 4 & 23,53 \\
$121,03-137,51$ & 2 & 11,76 \\
$137,52-153,99$ & 1 & 5,88 \\
& 17 & 100 \\
\hline
\end{tabular}


Untuk lebih jelasnya dapat dilihat pada histogram berikut:

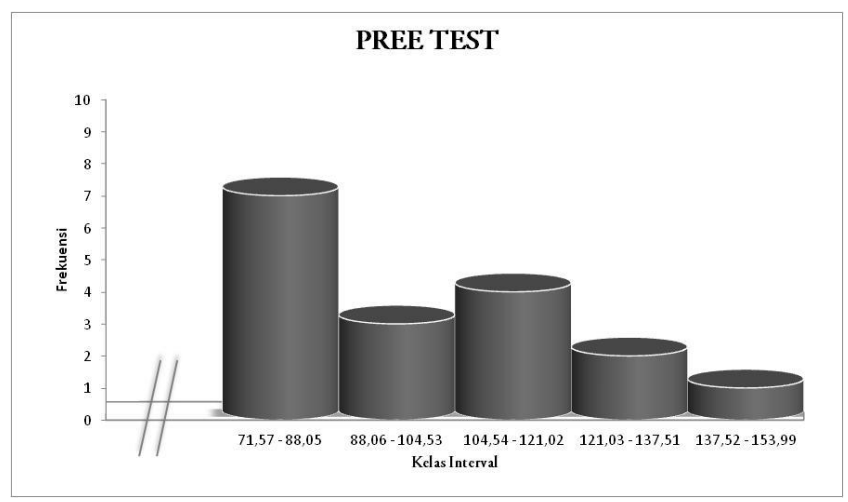

Gambar 2.Histogram Kelas Interval Pree Test

\section{Analisis data}

Setelah uji persyaratan analisis dilakukan dan ternyata semua data penelitian memenuhi persyaratan untuk dilakukan pengujian statistik lebih lanjut, maka selanjutnya dilakukan pengujian hipotesis, dalam penelitian ini ada satu hipoteis penelitian yaitu : Latihan Side-to-Side Shuffle Jump berpengaruh terhadap peningkatan daya ledak otot tungkai mahasiswa Penjaskesrek Universitas Bung Hatta. Berikut hasil analisis data:

Tabel 5.

Rangkuman Hasil Analisis Data

\begin{tabular}{ccccccc}
\hline Jenis Data & Mean & SD & $\mathbf{T}_{\text {Hit }}$ & $\boldsymbol{\alpha}$ & $\mathbf{T}_{\text {Tab }}$ & Ket \\
\hline Tes Awal (Post Test) & 98,26 & 25,82 & 6,22 & 0,05 & 2,11 & Signifikan \\
Tes Akhir (Pree Test) & 100,45 & 24,10 & & & & \\
\hline
\end{tabular}

Berdasarkan tabel 5 dapat dilihat bahwa thitung $(6,22)>$ ttabel $(2,11)$. Hal ini berarti bahwa hipotesis penelitian dapat diterima. Dengan demikian dapat disimpulkan bahwa Latihan Side-to-Side Shuffle Jump berpengaruh terhadap peningkatan daya ledak otot tungkai mahasiswa Pendidikan Jasmani, Kesehatan dan Rekreasi Universitas Bung Hatta, nilai selisih peningkatan yang ditemukan berdasarkan persentase sebesar 2,23\%.

\section{PEMBAHASAN}

Hasil penelitian membuktikan bahwa terdapat pengaruh latihan Side-toSide Shuffle Jump terhadap daya ledak otot tungkai Mahasiswa Penjaskesrek Universitas Bung Hatta. Sebelum diberikan perlakuan terhadap sampel terlebih dahulu dilakukan tes awal. Berdasarkan hasil tes tersebut ternyata daya ledak otot tungkai diperoleh Didapat nilai tes awal (Post Test) tertinggi 160,28 dan terendah 67,54 , dengan rata-rata 98,26. Namun setelah diberikan perlakuan dengan latihan Side-to-Side Shuffle Jump maka terjadi peningkatan dengan tertinggi 153,99 dan 
terendah 71,57, dengan rata-rata 100,45. Dengan hasil penelitian ini dapat disimpulkan bahwa latihan Side-to-Side Shuffle Jump berpengaruh terhadap daya ledak otot tungkai, hal ini diperkuat setelah dilakukan uji t, dimana diperoleh hasil bahwa thitung $(6,22)>$ ttabel $(2,11)$. Hal ini berarti bahwa hipotesis penelitian dapat diterima. Berdasarkan penelitian tersebut maka dapat kita simpulkan bahwa terdapat pengaruh latihan Side-to-Side Shuffle Jump terhadap daya ledak otot tungkai Mahasiswa Penjaskesrek Universitas Bung Hatta.

\section{SIMPULAN}

Berdasarkan analisis data dan pembahasan yang telah dipaparkan terdahulu, maka dapat dikemukakan kesimpulan. Latihan Side-to-Side Shuffle Jump berpengaruh terhadap peningkatan daya ledak otot tungkai mahasiswa Pendidikan Jasmani, Kesehatan dan Rekreasi Universitas Bung Hatta. Penting dipahami oleh pelatih dan asisten pelatih terkait memahami tentang manfaat program latihan, seperti yang dipapar di bab sebelumnya dapat digambarkan seberapa pentingnya sebuah program latihan sehingga tujuan latihan dapat tercapai dengan baik. Dengan program latihan yang baik diharapkan harapan dan tujuan atlet dan pelatih dapat tercapai dengan baik. 


\section{DAFTAR PUSTAKA}

Andryani, P., Devi. (2014). Pengaruh Pelatihan Side Jump Sprint Dengan Rasio Kerja:Istirahat 1:3 Dan 1:5 Terhadap Daya Ledak Otot Tungkai. Jurnal Ilmu Keolahragaan Undiksha. 2(1).

Bafirman. (2013). Kontribusi Fisiologi Olahraga Mengatasi Resiko Menuju Prestasi Optimal. Jurnal Media Ilmu Keolahragaan Indonesia, 3(1)

Kurniawan, C. (2013). Peningkatan Kebugaran Jasmani Melalui Program Latihan Jalan Cepat. Jurnal Penjaskesrek. (online), 1(4)

Syafruddin. (2013). Ilmu Kepelatihan Olaharaga, Teori Dan Aplikasinya Dalam Pembinaan Olahraga. Padang: UNP Press.

Widiastuti. (2015). Tes dan Pengukuran Olahraga, Jakarta: PT. RajaGrafindo Persada.

Yusuf, A., M. (2007). Metodologi Penelitian, Dasar-Dasar Penyelidikan Ilmiah. Padang: UNP Press.

Zulvikar, Januarshah. (2016). Pengaruh Latihan Core Stability Statis (Plank Dan Side Plank) Dan Core Stability Dinamis (Side Lying Hip Abduction Dan Oblique Crunch) Terhadap Keseimbangan. Journal of Physical Education, Health and Sport, 3 (2) 